\title{
Physico-chemical Characterization of Orange and Date Fruits Pulp
}

\author{
Swati Shukla ${ }^{1 *}$, Deepti Patel ${ }^{2}$ and Vijay Kumar ${ }^{3}$ \\ Department of fruit science, College of Agriculture, Indira Gandhi Krishi Vishwavidyala, \\ Raipur (C.G.), India \\ *Corresponding author
}

\section{A B S T R A C T}

\section{Keywords}

Orange, Date fruits, Total soluble solid, Acidity, Total sugar

Article Info

Accepted:

22 November 2020

Available Online:

10 December 2020
The current investigation was performed at fruit and vegetable Processing Laboratory under Department of Fruit Science of IGKV, Raipur (C.G.) during the year 2019-20. Date and orange fruits were scrutinized for physico- chemical qualities. Physical composition of date and orange fruits disclosed that average fruit weight was noted $47.78 \mathrm{~g}$ and $121.9 \mathrm{~g}$ respectively; peel weight $6.90 \mathrm{~g}$ and $32.04 \mathrm{~g}$ correspondingly. With respect to chemical constitution, total soluble solid was perceived $15.00^{\circ}$ brix and $10.72^{\circ}$ brix; ascorbic acid $4.56 \mathrm{mg} / 100 \mathrm{ml}$ and 43.46 $\mathrm{mg} / 100 \mathrm{ml}$; acidity $0.29 \%$ and $0.621 \%$; total sugar $18.44 \%$ and $9.63 \%$; reducing sugar $15.30 \%$ and $3.87 \%$, non-reducing sugar $3.14 \%$ and $5.76 \%$, in that order.

\section{Introduction}

Orange (Citrus reticulata Blanco.) is a evergreen tree belongs to family Rutaceae with chromosome number $2 n=2 x=18$. Orange is a winter fruit. Due to irrestible vivid colour, captivating taste and flavour, mandarin orange is one of the most well liked citrus fruit. Mandarin, Citrus reticulata refers to loose- skinned oranges. The orange fruit is a hesperidium. This is considered to be a native of tropical and sub-tropical Asia particularly south eastern Asia and Philippines. Oranges are extensively cultivated in tropical and subtropical climatic areas in favor of their scrumptious sweet fruit which is peeled or cut and eaten whole or juice which is used either fresh or processed to get squash, ready-toserve beverages, cordial and nectar etc. It's cultivation was first reported in China during 2500 years Before Christ. The production and utilization of oranges boost year by year. Globally, Brazil leads the world with production of orange approximately 35.6 million tons sharing about 30 per cent of the global harvest. As far as the position of India in the world is considered in respect to the acreage and production of oranges it ranks second in area and third in production. In India virtually $40 \%$ of total area are under citrus cultivation.

Generally, oranges are consumed in two forms i.e. as fresh and as juice. According to 
Etebu et al., (2014) citrus fruits have anticancer, anti-tumor and anti- inflammatory like numerous therapeutic properties. These properties are due to the photon- vitamins and nutrients present in the citrus fruits. Nagpur santra is the most important commercial cultivar of India. Galaverna et al., (20 14) stated that orange juice, Which is mainly consumed as fresh fruit juice is obtained by squeezing fruit endocarps. Because of its alluring colour, peculiar flavor and being affluent source of vitamin $B$ and $C, B$ carotene, calcium, phosphorus also utilized in various therapeutic and commercial purposes. Vitamin- ' $\mathrm{C}$ ' content ranges more than $65 \%$ in citrus. For enhancing the fragrance, taste, appetizing, nutrient significance and to reduce the acrimony of orange juice it was mixed with several other highly nutritive fruit juice or pulp.

Date palm (Phoenix dactylifera), is one of the most valuable fruit tree cultivated in both tropical and subtropical climates and belongs to the family Palmae (Arecaceae) having chromosome number of $2 n=36$. It is a dioecious, perennial, and monocotyledonous fruit tree. Its fruits are enriched with fiber, minerals, carbohydrates, and vitamins and as result of its great helpful nutrients and competence of boosting health it is well known across the world. Over the last forty years its production is in cred throughout the world. Rutab, Khalal and Tamr are three developmental junctures of date fruits and usually harvested at wholly matured stage named Tamr, i.e. when the Total Soluble Solids (TSS) content reaches $60-70^{\circ}$ Brix. The magnitudes of processed products of dates have been hurriedly and progressively mounting.

According to Al- Shahib and Marshall (2003) fruits of date palm hold a high proportion of carbohydrate $(44-88 \%)$, fat $(0.2-0.5 \%)$, proteins (2.3-5.6\%), tannins and a good percentage of dietary fiber (6.4-11.5\%). It enriches the human diet with high quality of a few compulsory amino acids (Shaba et al., 2015). 23 types of amino-acid are present in dates protein, some which are not found in the very famous fruits such as oranges, apples and bananas.

It is also a rich source of roughages which lowers the low density lipoprotein that prohibits from disease related to cancer and heart. It also comprises flavonoids, polyphenolic antioxidants identified as Tannins which has analgesic, anti-infective and anti-hemorrhagic properties. Vitamin ' $A$ ' is essential for maintaining the health of skin, mucosa and vision of eye. Dates are chief source of Vitamin A. Higher amount of potassium and iron are found in dates as regulation of heart rate and blood pressure by potassium and in red blood cells iron is the constituent of haemoglobin.

\section{Materials and Methods}

The present investigation entitled "Standardization of recipe and storage behaviour of orange (Citrus reticulata Blanco) squash fortified with date (Phoenix dactylifera) pulp" was conducted in the Horticulture Processing Laboratory Department of Fruit Science, College of Agriculture, Indira Gandhi Krishi Vishwavidyalaya, Raipur (C.G.) during the year 2019-20. Raipur area is located in the mid of state of Chhattisgarh which lies between $21.16^{\circ} \mathrm{N}$ latitude and $81.36^{\circ} \mathrm{E}$ longitudes having an altitude of 298 meters above the mean sea level. Fresh, ripe, fully mature and abrasion free orange and date fruits were selected for the preparation of blended squash, the chosen fruits were washed under running water to get rid of dirt and dust particles. The surface microbes and other contaminants were removed by washing with $5 \%$ hypochlorite 
solution and rinsed immediately several times with water. Oranges were sliced into two halves with stainless steel knife and juice was extracted using juice extractor. Juice was filtered using a muslin cloth.

Airtight screw cap and pre-sterilized glass bottles were used for storage filtered juice. Dates were cleaned from impurities and seeds removed. Cleaned dates were weighed and washed in water and blended in a juicer. During blending small amount of water was added to get homogenized and clear pulp. The pulp was put in a glass bottles and stored at $5^{\circ} \mathrm{C}$.

Before preparation of product randomly selected individual fruits were under weighed separately on electronic weighing balance and mean value of five randomly selected fruits was recorded in gram and were peeled and peel weight of orange and date fruits were recorded.

The ascorbic acid content of date pulp, orange juice along with prepared squash were determined by the procedure prescribed by Ranganna (1997). The titratable acidity of date pulp and orange juice were determined by the procedure given by Ranganna (1997).

Total soluble solids (TSS) measurement of date pulp and orange juice was done with help of hand refractometer at $20^{\circ} \mathrm{C}$. A drop of sample was placed over the prism and observation was taken and expressed in degree Brix $\left({ }^{\circ}\right.$ B). Sugars were determined by the method of Lane and Ranganna (1997). The reducing sugars were estimated by using Lane reported by Ranganna (1986a).Total sugars were also determined by volumetric method of Lane and by Ranganna (1986a). The $\%$ of non- reducing sugars of date pulp and orange juice was calculated by subtracting the $\%$ of reducing sugars from total sugars.

\section{Results and Discussion}

\section{Physico-chemical composition of orange and date fruits}

The physico-chemical composition of orange and date fruits were analyzed and discussed here.

Table.1 Physico-chemical composition of orange fruits

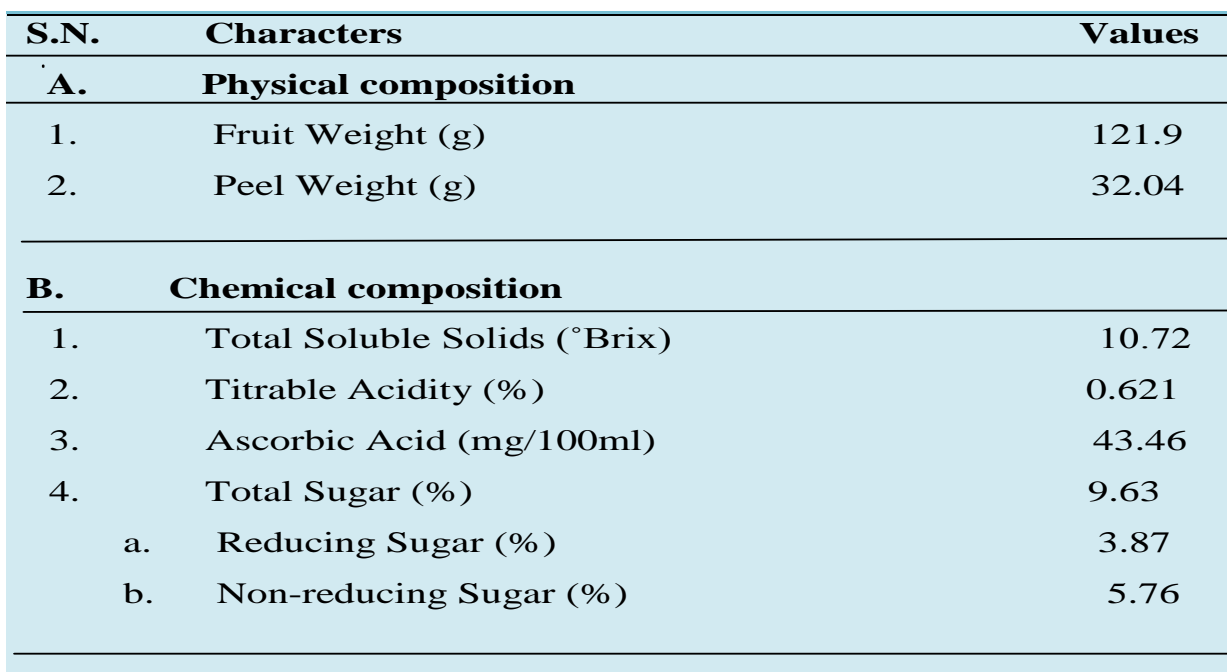


Table.2 Physico-chemical composition of date fruits

\begin{tabular}{|c|c|c|}
\hline S.N. & Characters & Values \\
\hline A. & Physical composition & \\
\hline 1. & Fruit Weight (g) & 47.78 \\
\hline 2. & Peel Weight (g) & 6.90 \\
\hline A. & Chemical composition & \\
\hline 1. & Total Soluble Solids ( ${ }^{\circ}$ Brix $)$ & 15.00 \\
\hline 2. & Titrable Acidity (\%) & 0.29 \\
\hline 3. & Ascorbic Acid (mg/100 ml) & 4.56 \\
\hline 4. & Total Sugar (\%) & 18.44 \\
\hline a. & Reducing Sugar (\%) & 15.30 \\
\hline b. & Non-reducing Sugar (\%) & 3.14 \\
\hline
\end{tabular}

Physico- chemical composition of orange juice

A crucial laboratory analysis of data on physical composition of orange fruit revealed that the average fruit weight and peel weight were recorded $121.9 \mathrm{~g}$ and $32.04 \mathrm{~g}$, correspondingly are presented in table 1 .

Data in relation to chemical composition of fruits divulged that mean value of total soluble solids (TSS) was recorded $10.72^{\circ}$ Brix. Total titrable acidity was recorded $0.62 \%$ in fruit juice sample. The mean value of ascorbic acid content was observed 43.46 $\mathrm{mg} / 100 \mathrm{ml}$. The mean value of reducing sugar, non-reducing sugar and total sugar were recorded $3.87 \%, 5.76 \%$ and $9.63 \%$, respectively. Khan A. et al., (2018) conducted an experiment to determination of the suitable blending of sweet orange juice and date fruit pulps. The similar observations were recorded by Bhosale et al., (2000) Nakadi et al., (2002) Wasker, (2003) Kayshar et al., (2014) Atulbhai Riddhi, M. (2015) and Raj et al., (2011).
Physico-chemical composition of date fruits

A decisive analysis of data on physical composition of date fruit showed that average fruit weight recorded was $47.78 \mathrm{~g}$ and peel weight was $6.90 \mathrm{~g}$ (Table 2).

The mean value of TSS was observed $15.00^{\circ}$ Brix. The mean value of acidity was recorded $0.29 \%$ whereas the recorded mean value of ascorbic acid was $4.56 \mathrm{mg} / 100 \mathrm{ml}$. Data also revealed that the mean value of total sugar, reducing sugar and non-reducing sugar were $18.44 \%, 15.30 \%$ and $3.14 \%$, respectively. Byanna et al., (2013) standardized the recipe for preparation of sweet orange and find the $15 \%$ juice, $15^{\circ}$ Brix and $0.3 \%$ acidity. Similar trends were also found by Chikkasubbanna and Reddy (2008) Tripathi et al., (1992) Malav, M. (2012) Shanmugam (2004) and Punam et al., (2012).

\section{References}

Al- Shahib, W. and Marshall, R.J. 2003. The fruit of the date palm: its possible use as the best food for the future? 
International Journal of Food Science and Nutrition 54(4): 247-259.

Atulbhai, Riddhi, M. (2015). Studies on feasibility of blending custard apple with banana for preparation of nectar. M.Sc. Thesis, ASPEE College of Horticulture and Forestry, Navsari Agricultural University, Gujarat.

Bhosale, V.I., Kute, L.S. and Kadam, S.S. (2000). Studies on preparation of ready -to-serve beverage from anola: mango juice blend. Beverage and Food World, 27(9): 24.

Byanna, C.N. and Gowda, I.N. 2013. Standardization of sweet orange and kokum blended RTS beverage using sugar substitutes. The asian journal of horticulture. 8(1): 164- 169.

Chikkasubbanna, V. and Reddy, A.H. 2008. Standardization of recipe and storage behaviour of lime blended amla squash. Asian J. Horticulture. 3 (2): 203-207.

Etebu, E., Nwauzoma, A.B. (2014). A review on sweet orange (Citrus sinensis Osbeck): health, diseases and management. American Journal of research.

Galaverna, G. and Dall' Asta ， C. 2014. Production Processes of Orange Juice and Effects on Antioxidant Components. Elsevier, Amsterdam. 203-214. https://doi.org/10.1016/B978-0-12404738-9.00021-0

Kayshar, M., Rahman, A.S., Sultana, M., Fatima, K. and Kabir, M. 2014. Formulation, preparation and storage potentiality study of mixed squashes from papaya, banana and carrot in Bangladesh.

Khan, M.A., Hashmi S., Muhammad, a., Muhammad, M., Bilal, H., and Wali, G. 2018. Development and storage study of orange date blended squash. Sarhad Journal of Agriculture. 34(3):
509-515.

Malav, M. (2012). Standardization and evaluation of orange based blended ready-to-serve (RTS) beverages. M.Sc. Thesis, College of Horticulture, Mandsaur (M.P.)

Nakadi, S.K., Kotecha, P.M. and Kadam, S.S. (2002). Studies on Ready-to-serve (RTS) beverage based on pomegranate and mango. Beverage and Food World, 26 (3), 36-39.

Punam, R., Singh, G. R. and Siddiqui, S. (2012). Development and evaluation of bael- mango ready-to-serve drink and squash. Beverage \& Food World. 39(4): 43-45.

Raj, D., Sharma, P.C. and Vaidya, D. 2011. Effect of blending and storage on quality characteristics of blended sand pear-apple juice beverage. J. Fd. Sci. Technol., 48(1): 102-105.

Ranganna, S. 1997. Handbook of analysis and quality control for fruit and vegetable products. Tata McGraw Hill Publishing Co. Ltd., New Delhi.

Shaba, E., Damisto, M.N., Mathew, J., Etsunyakpa, Tsado, A. ans Muhammad, S. 2015. Nutritional and anti- nutritional composition of date palm (Phoenix dactylifera L.) fruits sold in major markets of Minna Niger State, Nigeria. Afr. J. Pure Appl. Chem. 9:167-174. https://doi.org/10.5897/AJPAC2015.0 643

Shanmugam, S. A. (2004). Processing on mixed fruit squashes. Published Master thesis, Department of Food Science and Nutrition, Home Science College and Research Institute, Tamil Nadu Agricultural University, Madurai.

Tripathi, V.K., Lyndgoh, K. and Singh, S. 1992. Studies on blending of pineapple juice with different ratio of guava juice for preparation of RTS beverage. Prog. Hort., 24(1-2): 60-63. 
Wasker, D.P. (2009). Studies on improvement in colour of pomegranate juice by blending with kokum juice. ISHS Acta Horticulture 890: II international symposium on pomegranate and minor - including Mediterranean- fruits: ISPMMF 2009.

\section{How to cite this article:}

Swati Shukla, Deepti Patel and Vijay Kumar. 2020. Physico-chemical Characterization of Orange and Date Fruits Pulp. Int.J.Curr.Microbiol.App.Sci. 9(12): 3093-3098.

doi: https://doi.org/10.20546/ijcmas.2020.912.367 